DOI 10.15826/qr.2016.2.157

УДК 930(470)"4968"+327.54+327.8(73:470)

\title{
1968: ONE YEAR IN THE LIFE OF A SOVIET AMERICANIST, OR AMERICAN INFLUENCE AT HOME AND ABROAD DURING THE COLD WAR*
}

\author{
Sergei Zhuk \\ Ball State University, \\ Muncie, Indiana, USA
}

This essay is based on the author's recent research about American studies in the Soviet Union during the Cold War. Using various archival documents, personal papers, diaries, memoirs, contemporary periodicals, and more than 70 interviews, this essay explores how one year, 1968, changed the life of Nikolay N. Bolkhovitinov (1930-2008), a Soviet historian and the author of pioneering studies on Russo-American relations. During this year, Bolkhovitinov used funding from the American Council of Learned Societies (ACLS) to support his first research trip to the USA, where he intended not only to discover 'the real America' through various forms of cultural consumption, but also to build his international reputation as a historian of early America and an expert in Russo-American relations.

Keywords: American studies; knowledge production; US-Soviet relations; Cold War.

Очерк основан на материалах нового исследования автора по истории советской американистики времен холодной войны. С использованием различных архивных документов, личной переписки, дневников, мемуаров, современных периодических изданий и более 70 интервью в очерке исследуется, как события 1968 г. изменили течение жизни Николая Болховитинова (1930-2008), советского историка, автора оригинальных исследований начала истории российско-американских отношений. В указанный год Болховитинов благодаря финансированию Американского совета ученых обществ совершил научную поездку в США, за время которой он не только открыл для себя реальную Америку через различные формы культурного потребления, но и начал создавать себе

* Citation: Zhuk, S. (2016). 1968: One Year in the Life of a Soviet Americanist, or American Influence at Home and Abroad during the Cold War. In Quaestio Rossica. Vol. 4. № 2, p. 15-42. DOI 10.15826/qr.2016.2.157.

Цитирование: Zhuk S. 1968: One Year in the Life of a Soviet Americanist, or American Influence at Home and Abroad during the Cold War // Quaestio Rossica. Vol. 4. 2016. № 2. P. 15-42. DOI 10.15826/qr.2016.2.157.

(C) Zhuk S., 2016

Quaestio Rossica • Vol. 4 • 2016 • № 2, p. 15-42 
международную репутацию историка ранней Америки и эксперта по истории российско-американских отношений.

Ключевые слова: советская американистика; производство знания; советско-американские отношения; холодная война.

Overall, the recent research in Western and Russian post-Soviet historiography about knowledge production during the Cold War ignores the role of the pioneers of 'academic détente' (the improvement of relations between US and Soviet scholars): one such individual was Nikolay N. Bolkhovitinov (1930-2008), one of the founders of American studies in the Soviet Union. ${ }^{2}$

The real rise of Bolkhovitinov's academic career took place after the successful defence of his doctoral dissertation on the origins of RussoAmerican relations in 1965: this coincided with the Brezhnev era, otherwise known as 'the era of stagnation.' 'As far as I can recall we did not feel in October-November 1964 that something had changed since the replacement of Khrushchev with Brezhnev', Bolkhovitinov noted in one of his interviews:

Everything looked the same. I remember only the feeling of relief my wife and I shared when Khrushchev had gone. Everybody, including us, was tired of Khrushchev's experimentation and his unpredictability. We did not appreciate that we had lived through the great era of new hopes and expectations under Khrushchev. Only after 1968, after the suppression of the 'Prague Spring', did I realise finally that all our hopes for socialist reforms were over, and Lyudmila and I really began missing Khrushchev's era. But during 1964-1966, I was so busy with my doctoral dissertation that I did not pay special attention to the political situation, which did not directly affect my life those days. ${ }^{3}$

\section{American influences at home}

In the spring of 1965, Bolkhovitinov met for the first time his American colleague Lyman Henry Butterfield, the director of the Institute of Early American History and a historian of the early American Republic who was involved in the publication of the papers of the Adams' family. Professor Butterfield came to Moscow looking for archival documents relating to John Quincy Adams' mission to imperial Russia in 1809-1814. In April, Butterfield asked the administration of the American Council of Learned Societies (ACLS) to help him to organise this visit in Moscow. Frederick Burkhardt, ACLS president, requested that S. K. Romanovsky, chairman of the USSR State Committee for Cultural Relations with Foreign Countries, 'receive this American scholar and provide him with necessary contacts' in the USSR Academy of Sciences:

${ }^{2}$ Among numerous recent publications, only one has emphasised the role of Nikolay Bolkhovitinov [Russian/Soviet Studies...]. Compare with my old publication: [Zhuk, 2013a].

${ }^{3}$ Interview with N. N. Bolkhovitinov, Moscow, 10 July 2004 (here and further on in the article, unless indicated otherwise, all the interviews of N. Bolkhovitinov and his colleagues are cited from recordings kept in the author's private collection). For the Soviet people's reaction to Khrushchev's fall, see the memoirs of Bolkhovitinov's contemporaries and colleagues: [Arbatov, p. 104-141; Познер, с. 306-307; Черкасов, с. 201-209]. 
I enclosed a letter... to Academician [Isaak Izrailevich] Mints about the proposed visit to the Soviet Union of Dr. L. H. Butterfield. Dr. Butterfield expects to travel as a tourist and to leave this country for the Soviet Union on May 14... regards The Adams Papers, of which Dr. Butterfield is Editor in Chief, as a most important historical project [ACLS]. We shall be grateful for any assistance you can give Dr. Butterfield in meeting Soviet scholars and in obtaining access to appropriate materials. ${ }^{4}$

Meanwhile, Butterfield had already read an article written by Bolkhovitinov about Russian diplomacy and the American Revolution, which was published in English translation in a series edited by M. E. Sharpe [Болховитинов, 1964a, с. 31-46]. This is why Butterfield immediately referred to Bolkhovitinov as 'the only world-renowned Soviet specialist in the history of early Russo-American relations in Moscow' during his first meeting with officials from the USSR Academy of Sciences. After this conversation, the representatives of the international department from the Institute of History directed the American guest to Bolkhovitinov. These officials supervised a few meetings between the young Soviet Americanist and Butterfield in various Moscow archives. It was a unique experience for Bolkhovitinov to be able to share his professional expertise with a famous American historian. Although the KGB followed the American throughout the trip, Bolkhovitinov very much enjoyed these few days of collaboration with Butterfield. Bolkhovitinov used his spoken English for professional discussions for the first time, helping Butterfield to locate the archival files related to Quincy Adams' visit to Russia, especially the 'notes exchanged with [Russian] Chancellor Rumyantsev and the instructions and dispatches sent by and to the Russian Foreign Office and its representatives in the United States.'5

Bolkhovitinov was instrumental not only in finding all these archival files for the American visitor, but also in arranging to have them copied on microfilm. Grateful for this help, Butterfield later arranged for all the materials related to Russia in the Adams Papers in the Massachusetts Historical Society to be copied and sent to Moscow for the use of Soviet scholars. Bolkhovitinov was the first Soviet historian to incorporate all of the appropriate information from this collection into his own research: he did so in the autumn of 1965, when the first microfilm reels reached Moscow. Throughout his life, Bolkhovitinov preserved his memories of this first personal 'academic exchange' with the American historian, which affected not only his research, but also his perception of historical scholarship in the United States. As he was to note later, 'for my entire life, Professor Butterfield became for me a living symbol of a decent and professionally competent historian from the West.'

This meeting with the American scholar led to Bolkhovitinov's first encounter with KGB officers from the Institute's international department. They approached Bolkhovitinov in early 1965 because they had 'a special

\footnotetext{
${ }^{4}$ Letter of April 19, 1965 from Frederick Burkhardt, ACLS President, to Mr. S. K. Romanovsky, Folder "Correspondence with State Committee for Cultural Relations with Foreign Countries" [Exchange agreements between the US and USSR, 1958-1968 // ACLS. F. 2. P. 789 ].

${ }^{5}$ Interview with Robert Ivanov, Moscow, 19 March 1991 [Butterfield, Levin, p. 17].

${ }^{6}$ Interview with N. N. Bolkhovitinov, Moscow, 12 June 1991.
} 
written request from Professor Butterfield about his plan to meet a particular Soviet scholar - Nikolay Bolkhovitinov'. One of these officers instructed Bolkhovitinov about 'what to do and how to behave with an American visitor.' Moreover, this officer reminded him to write a 'special report about the conversations [with Butterfield]', which Bolkhovitinov had to submit immediately ('two days maximum') after his meetings. Reluctantly following the KGB officer's instructions to the letter, Bolkhovitinov spent an entire afternoon in May 1965 reporting '(1) the biography and scholarship of Professor Butterfield, (2) the topics of the discussed issues and conversations during the meetings with this American guest, and (3) the various thoughts, considerations, suggestions and propositions, expressed by Professor Butterfield.' The entire procedure of organising the meetings with Butterfield and the subsequent contacts with the KGB were Bolkhovitinov's most lasting impressions from the spring of $1965 .{ }^{8}$

Another influence on Bolkhovitinov during this period of transition from Khrushchev to Brezhnev was the 'new wave' of American popular culture, which influenced even middle-aged intellectuals like the Bolkhovitinovs through a 'sudden influx' of American movies in Moscow theatres during 1964-66 [Raleigh, 133-135]. This trend was noted by Bolkhovitinov and fellow Americanists such as Nikolay Sivachev and Robert Ivanov. Moreover, as Bolkhovitinov later recalled, during the spring of 1965, he, a few of the Soviet experts in US politics and culture, and many Soviet scientists were invited by officials from the Central Committee of the CPSU for a special 'closed screening' of two American anti-war movies to decide whether they were appropriate for Soviet audiences. One of these films was Stanley Kramer's On the Beach (1959) while the other was the British-American Dr. Strangelove (1964), directed by Stanley Kubrick. Although all the Soviet Americanists who attended the screening recommended these films for a wider release, they were never shown in the Soviet Union, since their vision of the 'graphic results of nuclear war' was 'too intimidating for a normal Soviet viewer.' However, other, less 'intimidating' films 'made in the USA' were on the screens of all Moscow's major movie theatres. ${ }^{9}$

Even the Moscow International Film Festival in the summer of 1965 featured prominently not only American movies, but also real American movie stars like Steve McQueen, a favourite among Soviet fans of the western The Magnificent Seven, and Carroll Baker, who met with the Soviet public and was interviewed by Soviet journalists. ${ }^{10}$ Using the personal connections of his father in the USSR Academy of Sciences, Bolkhovitinov obtained a few tickets to see some of the films shown at the festival between 6 July and 20 July 1965. ${ }^{11}$ After seeing these

${ }^{7}$ This was a typical KGB requirement for all personnel of the Soviet Academy of Sciences and the universities [Черкасов, с. 315].

${ }^{8}$ Interview with N. N. Bolkhovitinov, Moscow, 12 June 1991.

${ }^{9}$ Interview with N. N. Bolkhovitinov, Moscow, 10 July 2004. See also: [English, p. 106].

${ }_{10}$ About the popularity of American movies in Moscow in may 1964, see: [Карцева, c. 16]; see also: [Советский экран, 1965, № 13, с. 24] and the back page with a photo of Caroll Baker, and the front page of no. 14 with a photo of Steve McQueen [Roth-Ey, p. 115-120].

${ }^{11}$ For a detailed description of the Moscow International Film Festival in 1965, see: [Советский экран, № 16, с. 1, 6]. 
movies, he was frustrated with the low quality of American 'commercial films': After watching recently in local movie theatres such talented and serious movies like On the Beach, Dr. Strangelove, and The Catered Affair, we were shocked with the obviously commercial character of the films presented by American guests during the festival... Many of us could not understand why the festival judges awarded the Silver Prize for the best movie to the cheap and silly American comedy The Great Race (Bol'shie gonki). ${ }^{12}$

As Bolkhovitinov noted, it was 'another disappointment' in relation to the United States. As far as I can recall, the assassination of Kennedy in 1963 was my first real disappointment which destroyed my old illusions about the USA. This stupid comedy film by Blake Edwards about the 1908 New YorkParis automobile race with talented American actors like Jack Lemmon, Tony Curtis, and Natalie Wood demonstrated how the American film director's pursuit of the low tastes of the public, driven by a desire to make money by attracting this public to the movies, would lead to the 'commercial killing' of cinematic art. In contrast to the serious American movies presented during the Moscow festival, films like To Kill a Mockingbird and The Defiant Ones (in the Russian release - Bonded by One Chain), The Great Race was another disappointment with America, revealing the purely entertainmentfocused and commercial character of American culture. Paradoxically, these revelations about American mass culture not only fit our prevailing Soviet ideological clichés about American capitalist civilisation, but also contributed to my new sceptical attitude towards western capitalism. ${ }^{13}$

\section{Everyday working routine}

From the 1960s, Bolkhovitinov's life completely depended on the academic politics and practices within his research institute, the Institute of History (after 1968, the Institute of World History) at the USSR Academy of Sciences. These practices remained the same after the overthrow of Khrushchev. Many of Bolkhovitinov's colleagues from the Institute of History confirmed that 'nothing changed dramatically' in the routine of their academic lives after 1964. ${ }^{14}$ They still had only two 'office days' (prisutstvennye dni) (usually Mondays and Wednesdays) per week, when they worked in their offices for a couple of hours. Soviet scholars from academic institutions such as the Institute of History in Moscow only had to attend official meetings once a week (usually on Wednesdays). All other

\footnotetext{
${ }^{12}$ Bolkhovitinov's letter, Moscow, 29 January 1997. Bolkhovitinov is mistaken about the exact name of the prize. In Moscow, this film was awarded the so-called Silver Prize and a special prize for achievements in film technology. See: [Советский экран, № 16, с. 1]. It was released in the Soviet Union relatively late in 1976, ten years after its original release in the USA. In relation to The Catered Affair, Bolkhovitinov was referring to the 1956 movie known as Wedding Party, a family drama film directed by Richard Brooks. It was released in the USSR under the title Svadebnyi zavtrak (Wedding Breakfast).

${ }^{13}$ Interview with N. N. Bolkhovitinov, Moscow, 21 May 2001.

${ }^{14}$ See the memoirs of Soviet scholars who worked at the Institute of History: [Nekrich, p. 179-244; Гутнова, с. 258-271, 274-279; Гуревич, с. 208-239].
} 
days were so-called 'library days' when they were supposed to do research either in archives or libraries. ${ }^{15}$ This system of office days was typical for the institutes of the Soviet Academy of Sciences, especially in Moscow. Another contemporary described this system in ISKAN in the 1970s:

There is an 'office day'... at the Institute [of the USA and Canada]. And at different institutes these days are different. In my institute they were Monday, Wednesday, and Friday. We knew that Arbatov [the director of the Institute of the USA and Canada] would appear after lunch... or sometime after 3. So after 3 he should show up... At the Institute of the International Workers' Movement, they had a better position: they had only two office days. They had Tuesdays and Fridays... Many researchers, then, did their work at home. Library and security regulations were circumvented [op. cit.: Dash, p. 198, 199].

Compared to the heavy teaching loads and service obligations at the provincial colleges and universities, a job at the academic institutes was considered to be 'a great privilege, a scholarly paradise' or, as Aleksandr Fursenko called it, an 'academic sinecura (a careless life).'16 A 'normal' teaching load for a professor of history at Moscow State University (MGU) was two or three courses per semester, while the average teaching load at the provincial Soviet universities in Dnepropetrovsk and Odessa was four to six courses per semester. ${ }^{17}$

Bolkhovitinov acknowledged that he and his colleagues had much better conditions for research than scholars teaching in Soviet colleges. As he later explained:

On average during 1964-66, I spent six to eight hours every day either in the library or at home, writing or rewriting my material, first for my doctoral dissertation and then for my book. Frankly speaking, I visited the Institute only once a week, sometimes once every two weeks. I had a plenty of time to sleep, relax, and think about revising my material. ${ }^{18}$

Using his free time productively, Bolkhovitinov prepared a series of scholarly articles that eventually became the chapters of his doctoral dissertation: they were subsequently incorporated into a book which he published in $1966 .{ }^{19}$

At the end of January 1966, Bolkhovitinov began to prepare his doctoral dissertation for publication. The length of his manuscript was two times

\footnotetext{
${ }^{15}$ See interviews with Marina Vlasova, Vadim Koleneko and Sergei Burin on 20 February 1996, Moscow, and the e-mail message from Vladislav Zubok, 27 May 2013.

${ }_{16}^{16}$ Interview with Aleksandr Fursenko, Moscow, 19 March 1991.

${ }^{17}$ Interviews with Viktor Kalashnikov, Marina Vlasova and Aleksandr Mikhailyuk on 26 March 1992.

${ }^{18}$ Interview with N. N. Bolkhovitinov, Moscow, 21 May 2001.

${ }_{19}$ During 1965, all of his newly researched material was published as articles and chapters in various Soviet journals and books [Болховитинов, 1964а, с. 203-239; Он же, 19646, с. 73-88; Болховитинов, Семенов, с. 389-415; Болховитинов, 1965a, с. 153-159; Он же, 19656, с. 102-113].
} 
longer than was officially allowed by the Soviet academic press Nauka, the traditional venue for books by Moscow scholars employed at the Academy of Sciences. Bolkhovitinov's opponents tried to stop the publication of his manuscript in this prestigious Soviet academic press. However, constant strong support from his former mentor Aleksei Efimov, who had important connections with Nauka, protected Bolkhovitinov's manuscript. Eventually, under pressure from Efimov, Nauka's editors accepted the manuscript and approved its original uncut version. This was the happiest period of Bolkhovitinov's life. As he recalled later, 'the spring of 1966 was the happiest time in my entire life, nobody interfered in my manuscript preparation; all my corrections were accepted without any criticism' [Болховитинов, б. г., с. 46, 47]. ${ }^{20}$

Even his opponent G. Sevostyanov stopped harassing him for awhile. Between 1966 and 1968, Sevostyanov had very cordial relations with the young scholar and supported all Bolkhovitinov's initiatives, including the publication of his book. This was because Sevostyanov was trying to create a coalition of supporters in the 'American' department (sektor) in his plot to overthrow Boris Mikhailov, its old head. In this power struggle, Sevostyanov needed Bolkhovitinov's support. Therefore Bolkhovitinov had 'the best working conditions at the department ever' and 'surprisingly very friendly relations with Sevostyanov' for two years. ${ }^{21}$

The publication of his book in June 1966 made Bolkhovitinov 'the new young rising star' in Soviet American studies. He became famous as the youngest researcher of US history in the Soviet Union: his two books became the foundation for the serious and meticulous exploration of the history of the United States and Russo-American relations in the $18^{\text {th }}$ and $19^{\text {th }}$ centuries. As one of Bolkhovitinov's colleagues noted, the publication of this new book signified 'the birth of the Bolkhovitinov phenomenon in Soviet historiography' [Комиссаров, с. 16].

Professor Ilya Savvich Galkin, the chair of MGU's department of modern and contemporary history, invited the new celebrity to deliver lectures for the faculty and students of Moscow University. At the beginning of 1967, he asked Bolkhovitinov to write a review of a new textbook about the historiography of modern and contemporary Europe and America prepared by Galkin's colleagues from MGU. ${ }^{22}$ In the same year, Galkin offered Bolkhovitinov the teaching position of adjunct (or visiting) professor of history. Moreover, Galkin, who sincerely liked the young talented scholar, even promised him a future promotion to full professor [Болховитинов, б. г., с. 47-48]. ${ }^{23} \mathrm{How}-$ ever, a few of Bolkhovitinov's Americanist colleagues in Galkin's department felt unhappy about having such a successful and talented young historian as

${ }^{20}$ Interview with N. N. Bolkhovitinov, Moscow, 10 July 2004. Both Robert Ivanov and Igor Dementiev confirmed the existence of these anti-Bolkhovitinov intrigues at the Nauka publishing house during my conversations with them on 22 March 1991, Moscow.

${ }^{21}$ Interviews with Robert Ivanov and Sergei Burin, Moscow, 6 September 1998. Citations are from Bolkhovitinov's letter, Moscow, 29 January 1997.

${ }^{22}$ It was published in 1969 (with V. A. Dunaevsky as its co-author) in: [Вопросы истории, 1969, № 7, с. 151-155].

${ }^{23}$ See Galkin's biography in: [Дементьев]. See also his memoirs in: [Галкин]. 
their rival. Professor Igor Dementyev, a former student of Galkin's, began complaining about losing his students to this newcomer from the Institute of History. Eventually, as a result of this pressure, Galkin had to change his offer in 1967. Instead of the official position of adjunct professor, Bolkhovitinov got a much less prestigious and less lucrative teaching assignment. He was paid by the hour as a lecturer and there was no promise of a professorship. Bolkhovitinov kept teaching at MGU until 1974 on these conditions, sometime even supervising students' diploma work [Там же]. ${ }^{24}$

As Bolkhovitinov later recalled, the most remarkable year for his personal and academic work was 1968. First of all, the Institute of History was officially divided in two institutes, one dedicated to the history of the USSR and the other to world history. The department of 'American countries' was transformed into the department of USA and Canadian history and was moved to the Institute of World History. As a member of this department, Bolkhovitinov was promoted to senior research fellow (starshii nauchnyi sotrudnik). However, he was frustrated because he lost direct contact with experts in pre-revolutionary Russian history like A. A. Zimin, V. T. Pashuto, and A. A. Preobrazhenskii, the scholars who had inspired him in his own archival research. ${ }^{25}$

The major figure behind the reorganisation of the Institute of History in 1968 was Sergei Pavlovich Trapeznikov, an old friend of Leonid Brezhnev: he had worked with the Soviet premier since 1948 as the director of the Higher Party School in Moldavia. Afterwards, Brezhnev brought Trapeznikov to Moscow, where he made a good career: he was elected a member of the Central Committee of the CPSU in 1966 and made the Committee's head of the department of scientific and teaching institutions. In 1966, Trapeznikov tried to become a member of the Academy of Sciences, but an overwhelming majority of Soviet academicians (the active members of the Academy) voted against him. As a result, the humiliated Trapeznikov decided to take revenge. ${ }^{26}$ Another practical reason for the division of the Institute was the position of its communist party organisation, which rejected the official decision of the CPSU Central Committee to expel Aleksandr Nekrich from the party for his criticism of Soviet leadership during WWII [Болховитинов, 1997, с. 73; see also: Markwick, 203ff.].

According to Nekrich's memoirs, one of '[Trapeznikov's] many acts of revenge' included the aggressive division of the 'free-thinking' Institute of History. Many of its scholars were publicly critical about the deficient intellectual abilities and subpar academic expertise possessed by 'this party apparatchik', who officially specialised in 'Soviet agrarian history'. Therefore, through-

${ }^{24}$ Galkin tried to play a difficult game with his colleagues during his department meetings in the late 1960s. See: [Архив МГУ. Ф. 9. Оп. 8. Д. 962. Л. 14-22].

${ }^{25}$ As Aleksandr Nekrich noted in his memoirs, 'by decree of the Central Committee secretariat and the presidium of the Academy of Sciences, the Institute of History was divided in two: the Institute of USSR History and the Institute of World History' ('the organisation period lasted a year...') [Nekrich, p. 221].

${ }^{26}$ See also the first Soviet "unofficial" biography of Brezhnev: [Медведев, кн. 1, с. 64-65, $143-145]$ 
out the entirety of 1968, Trapeznikov personally supervised the division of this academic organisation into two very different institutions [Nekrich, p. 221]. As an 'expert' in Soviet history, he tried to create a special institute for the history of the USSR which would be loyal to him: he removed from its personnel those real experts in Soviet history who could be potential rivals. As a result of these manoeuvres, this institute became more conservative and 'lost academic leadership to the Institute of World History, whose personnel were still more open-minded and ready for dialogue with western historians.'27

Meanwhile, in 1968, Dr Sevostyanov, Bolkhovitinov's old opponent of, finally won his struggle for power in the department of American history and became its chair, thus changing the nature of its leadership. Instead of control by the Central Committee of the CPSU, which had been represented by Boris Mikhailov, the previous leader and an expert in the history of the international working class, Sevostyanov, a former intelligence officer, now reintroduced KGB control. He had already been working as acting chair (ispolniaiushchii obiazannostizaveduiushchego) as early as September 1967. Eventually, in April 1969, Sevostyanov's appointment was approved by the administration of the Institute of World History. ${ }^{28}$ During his first years in power, Sevostyanov treated Bolkhovitinov as his ally and supported his academic career, especially in 1968. When Bolkhovitinov reminded Sevostyanov about his need to go to the United States to continue his research in American archives and libraries, Sevostyanov not only publicly supported Bolkhovitinov's request, but also organised a special meeting to discuss Bolkhovitinov's so-called 'scientific plan' for his research trip abroad. However, Sevostyanov, who 'praised Bolkhovitinov's academic achievements in public', had at the same time always objected to Bolkhovitinov's applications in his conversations with officials from the Institute's international department [Болховитинов, б. г., с. 46]. ${ }^{29}$

\section{Bolkhovitinov's first trip to America in 1968}

Despite the secret objections of Sevostyanov, the international department eventually approved Bolkhovitinov's application 'for a business trip abroad' in January 1968. According to Bolkhovitinov, this was, for him, one of the most important events of that year. As a result of this visit, Bolkhovitinov not

\footnotetext{
${ }^{27}$ I quote my interview with Robert Ivanov, Moscow, 6 September 1998.

${ }^{28}$ See an official Soviet publication openly praising the professional background of Sevostyanov as a Soviet spy and KGB intelligence officer before his academic career in 1950. It was published as Nauchnaia zhizn (Scholarly Life) in Amerikanskii ezhegodnik during perestroika [Бурин, с. 211-215]. After his 'spy career' in both Byelorussia and the Far East during WWII, Sevostyanov was sent by the KGB to the Higher Diplomatic School of the Ministry of Foreign Affairs in 1947, from which he graduated with a kandidatskaia dissertation. He defended this dissertation in 1950, after which the KGB recommended him to the Institute of History. In 1960 he defended his doctoral dissertation and was appointed in September 1967 as acting head of the department of the history of the USA and Canada. In April 1969, Sevostyanov was officially approved as its chair. See also: [Новые члены Академии наук СССР; Григорий Николаевич Севостьянов]; and chapt. 6 of this book.

${ }^{29}$ Robert Ivanov also confirmed this fact (interview with Robert Ivanov and Vadim Koleneko, Moscow, 6 September 1998).
} 
only found new documents and literature in American archives and research libraries about the history of early Russo-American relations, but also established personal contacts with American experts in US history and the history of diplomacy. This visit exposed Bolkhovitinov to new information available through American mass media about the situation in his own country and the rest of the socialist bloc. Finally, this first (and longest) visit to the United States revealed to Bolkhovitinov new aspects of American everyday life and civilisation, which allowed him to change his 'preconceived and ideologically biased perceptions of American realities. ${ }^{30}$

Bolkhovitinov began applying for permission to go to the United States as early as 1959, when the first rumours regarding Soviet-American agreements on academic exchanges reached his colleagues at the Institute of History. Moreover, some Americanists from Moscow State University and Bolkhovitinov's 'American department', such as Nikolay Sivachev and Irina Beliavskaya, had already travelled on a regular basis to the West, and America in particular, through these Soviet-American agreements. As Aleksandr Nekrich recalled, at the end of the 1950s and during the 1960s, Soviet historians 'from the department of US and Canadian history were working in the archives at libraries in the United States, some having been there two or three times. ${ }^{31}$

In 1960, after failing so many times with his applications for a business trip to America, Bolkhovitinov approached officials from the Institute's international department and asked them frankly about 'what to do to expedite the process of his travel applications.' These officials (who were directly connected to the KGB) suggested that he first become a member of the communist party and then apply for tourist travel to the socialist countries of Europe 'to demonstrate his ideologically correct behaviour while traveling abroad.' They reminded him that he had to fill out a special form for travel abroad called a spravkaobektivka, which would reflect not only the details of his biography, including information about the arrest of his father in the 1930s, but also his previous personal contacts with foreigners. ${ }^{32}$ Bolkhovitinov followed these suggestions, joining the Institute's communist party organisation in 1961 and then applying for a trip to socialist Czechoslovakia, which he visited in 1963 as a tourist with a group of representatives from the Soviet Academy of Sciences. ${ }^{33}$ As Bolkhovitinov revealed later, his 'opening of the capitalist West' started with his visits to such socialist countries as Czechoslovakia in 1963 and Poland, Hungary, and Bulgaria in 1966. After these visits, the most important revelation

\footnotetext{
${ }^{30}$ Interview with N. N. Bolkhovitinov, Moscow, 12 June 1991.

${ }^{31}$ See detailed information about the visits to the USA of Bolkhovitinov's colleagues from the Institute of History, such as Irina Beliavskaya, Viktor Malkov, Boris Mikhailov, and Grigory Sevostyanov, during the academic year of 1962-63 in Exchange agreements between the US and USSR, 1958-1968 [ACLS. F. 2. P. 789], ACLS, folder "Programs of Exchanges of Scholars in the Humanities and Social Sciences between the ACLS and the Academy of Sciences of the USSR" (Revised on 11/19/1968), p. 2.

${ }^{32}$ Regarding the documentation for visits to foreign countries, see: [Dash, p. 11-12; Черкасов, с. 216]; especially endnote 2 about the spravka-obektivka of Nikolay Inozemtsev, the director of IMEMO.

${ }^{33}$ Interview with N. N. Bolkhovitinov, Moscow, 10 July 2004.
} 
for him was the level of openness to 'Western capitalist influences' in Eastern Europe compared to that in contemporary Soviet society. Bolkhovitinov recalled that not only were some elements of 'western mass media', such as British and West German periodicals, available in local newsstands, but also 'the completely different (from our Soviet) mentality and perception of the outside world among Eastern European intellectuals, including the local historians. ${ }^{34}$

'Moreover, I became envious', Bolkhovitinov noted, 'of the East European level of freedom and how our socialist colleagues from neighbouring Eastern European countries could easily connect with intellectuals from the West, especially with scholars from the United States of America. ${ }^{35}$ Many of Bolkhovitinov's colleagues were also inspired by their communication with historians from the countries of 'the socialist camp'. As Aron Gurevich, a famous Soviet medievalist and Bolkhovitinov's colleague, recalled in his memoirs about his first visit abroad to socialist Poland in 1967, his conversations and discussions with Polish historians like Stanislav Pekarchyk, who had invited him to visit Warsaw, opened new intellectual horizons. Influenced by French representatives of the Annales school, who had visited Poland just one year before Gurevich and delivered lectures about their theoretical approach, his Polish colleagues shared with him their sincere admiration for current French historiography and Western 'freedom of expression and imagination.' These Polish hosts joked about living in the 'socialist camp': 'yes, it is true that both Soviet historians and Polish scholars live in the same socialist camp, but the life in our Polish "camp" barracks is much happier (veseleie) than in your Soviet barracks' [Гуревич, с. 187].

After his trips to Eastern Europe, Bolkhovitinov kept visiting the international department of the Institute of History on a regular basis, reminding its officials about his applications for a business trip to the United States. In November 1967, these officials surprised Bolkhovitinov by informing him about 'an open vacancy' in 'the list of candidates for the research trip to the capitalist countries.' According to contemporaries who had lasting connections with the Institute's international department, 'various assistants from the apparatus of the CPSU Central Committee supported Bolkhovitinov's candidacy for a research trip to America, referring to his unique expertise and his help in providing Soviet diplomats with important historical facts about Russo-American diplomatic relations.'36 $^{36}$

${ }^{34}$ Bolkhovitinov's letter, Moscow, 29 January 1997. With regards to the notion of 'openness' in Soviet society after Stalin, see: [Zhuk, 2011, p. 123-158].

${ }^{35}$ Bolkhovitinov's letter, Moscow, 29 January 1997.

${ }^{36}$ One of Bolkhovitinov's former colleagues, the Americanist Ivan Krasnov, complained that 'Bolkhovitinov's name was especially supported by Adzhubei's former people from the Central Committee.' Both Vadim Koleneko and Robert Ivanov, who had very good personal connections with the Institute of World History's international department, noted 'the special relations between the Central Committee's advisers and Bolkhovitinov' (I quote interviews with Vadim Koleneko, Robert Ivanov, and Marina Vlasova, 21 March 1991, Institute of World History, Moscow). Vlasova's father worked for the CPSU Central Committee's apparatus. Using these connections, Vlasova invited Bolkhovitinov to sit on her kandidatskaia dissertation panel at the MGU department of history in 1986. 
In early December 1967, after frequent visits to the international department to provide its officials with the necessary paperwork (official letters of recommendation from the Institute's communist party and trade union organisations), Bolkhovitinov finally received approval for a research trip of six months to the United States as an exchange scholar in the cooperative programme between the American Council of Learned Societies (ACLS) and the Soviet Academy of Sciences. According to ACLS documents, the Soviet organisers were still hesitant about Bolkhovitinov's candidacy and kept 'the vacancy in the exchange list' open for a very long time: it was not until November 1967 that Bolkhovitinov's name was finally approved and sent to America as an additional 'Soviet exchange scholar-historian.' ${ }^{37}$ On 7 December 1967, ACLS officially accepted Bolkhovitinov's nomination 'for a six-month visit to the US'. By New Year's Eve in 1968, Bolkhovitinov's name was submitted to the USSR Ministry of Foreign Affairs, and he was officially allowed to go to the United States from February to August $1968 .^{38}$

A few weeks before this trip, in January 1968, Bolkhovitinov received a phone call from the Institute's international department about the need for a 'special conversation with and instructions from the travel experts' of this department. When Bolkhovitinov came to the office, he was introduced to a young gentleman who called himself 'a travel expert'. After a very long conversation about the research plans for Bolkhovitinov's trip to America, this 'travel expert' proposed that they continue this 'interesting talk' in an 'unofficial and informal atmosphere.' This 'travel expert' gave the address of his own apartment and asked Bolkhovitinov to visit next day. As Bolkhovitinov later recalled, this apartment in downtown Moscow was 'a secret rendezvous place' arranged by the KGB: the 'travel expert' was an undercover KGB officer. During the next meeting in the apartment, this officer made Bolkhovitinov a 'direct offer' to collaborate with the KGB and 'politely requested' that Bolkhovitinov provide them with 'special information' during his trip in America. Shocked by such a proposal, Bolkhovitinov could not respond at first, stammering: he then decided to 'play the fool [igrat' duraka]'. ${ }^{39}$ After five minutes of silence, Bolkhovitinov promised the officer that he would think his offer over and then contact him via the special telephone number that had been provided. However, Bolkhovitinov never called the KGB officer back and rejected any future meetings with this 'expert', finding various excuses. Bolkhovitinov was afraid that his rejection of collaboration with the KGB would result in the

\footnotetext{
${ }^{37}$ See the folder "Programs of Exchanges of Scholars in the Humanities and Social Sciences between the ACLS and the Academy of Sciences of the USSR," Exchanges in 1966-1967 for 1968 page 5, in II : 789: Exchange agreements between the US and USSR, 1958-1968 // ACLS.

${ }^{38}$ Interview with N. N. Bolkhovitinov, Moscow, 10 July 2004; [Болховитинов, б. г., с. 47; Butterfield, Levin, p. 18]. See also: [Exchange agreements between the US and USSR, 1958-1968 // ACLS. F. 2. P. 789; ACLS, Library of Congress, Manuscript Collection, Folder "Administration of IIE [Institute of International Education (New York)]," Letter of December 7, 1967, from Charlotte Bowman, ACLS Administrative Secretary, to Mrs. Ann Doherty, IIE: 'I enclose a copy of a translation of a letter from the Academy of Sciences of the USSR, dated November 11, but only recently received, in which N. N. Bolkhovitinov is nominated for a six-month visit... (We didn't take time to translate the last two pages - Mr. Bolkhovitinov's bibliography.)'

${ }^{39}$ Interview with N. N. Bolkhovitinov, Moscow, 10 July 2004.
} 
cancellation of his trip. Surprisingly, the very same officer visited Bolkhovitinov's house a few days before his departure to the United States. Frightened, Bolkhovitinov invited the officer for a cup of tea and, after a long conversation, promised to meet him again after the trip to resume 'their negotiations'. Bolkhovitinov explained that 'he was too busy packing and mentally preparing for his trip to continue this serious conversation.' Despite all these tricks to avoid 'negotiations' about collaboration with the KGB, Bolkhovitinov was still afraid that the journey would be cancelled. Even as he touched down in New York in February, he believed that his 'travel would be stopped by the KGB. ${ }^{\text {' }}{ }^{4}$

Большинство современных исследований западной и российской историографии о гуманитарной науке в период холодной войны не в должной степени оценивают роль таких пионеров «академической разрядки», как Николай Николаевич Болховитинов (1930-2008), один из основателей американистики в Советском Союзе $\mathrm{e}^{41}$.

Взлет академической карьеры Николая Болховитинова начался в 1965 г. после успешной защиты докторской диссертации о начале российско-американских отношений. Этот период правления Леонида Брежнева известен как эпоха застоя, хотя сам Болховитинов отмечал в одном из интервью:

Честно говоря, насколько я припоминаю, мы не очень почувствовали какие-то изменения в октябре-ноябре 1964 г. в связи с заменой Хрущева Брежневым. <...>

Все выглядело без изменений. Правда, я вспоминаю, что я и жена вздохнули с облегчением, когда узнали, что Хрущева сняли. Все, включая нас, устали от хрущевских экспериментов и его непредсказуемости. Мы даже не успели оценить, что мы жили в великую эпоху надежд и больших ожиданий при Хрущеве. Только после 1968 г., после подавления «Пражской весны», я окончательно осознал конец всем нашим надеждам на реформирование социализма; а Людмила (жена Болховитинова. - С. Ж.) и я стали ощущать, что нам недоставало хрущевской эпохи. Но на протяжении 1964-1966 годов я был настолько занят докторской диссертацией, что особо не обращал внимания на политическую ситуацию в стране, которая напрямую меня не затрагивала ${ }^{42}$.

${ }^{40}$ Quotations from my interview with N. N. Bolkhovitinov, Moscow, 10 July 2004; see also: [Болховитинов, б. г., с. 49-50].

${ }^{41}$ Среди недавних многочисленных исследований о холодной войне см. единственное исследование, в котором подчеркивается роль Николая Болховитинова [Russian/Soviet Studies...]. Ср. с недавней публикацией: [Zhuk, 2013a].

${ }^{42}$ Интервью с Николаем Болховитиновым, Москва, 10 июля 2004 г. Здесь и далее, если не указано иначе, все интервью с Н. Болховитиновым и его коллегами цитируются по аудиозаписям из личного архива автора статьи. Ср. с мемуарами: [Arbatov, p. 104-141; Познер, с. 306-307; Черкасов, с. 201-209]. О детстве и студенческих годах Болховитинова и о влиянии на его академическую карьеру американского кино, джаза и его учителей А. В. Ефимова и Л. И. Зубока в Московском государственном институте международных отношений (МГИМО) в 1948-1953 гг. см.: [Zhuk, 2013b]. 


\section{Американские влияния внутри Советского Союза}

Весной 1965 г. впервые в своей жизни Николай Болховитинов встретился лицом к лицу с американским коллегой, историком ранней Американской Республики Лайманом Генри Баттерфилдом, директором Института ранней американской истории, который занимался публикацией бумаг семьи Адамса. Профессор Баттерфилд прибыл в Москву в поисках архивных документов, касавшихся миссии Джона Куинси Адамса в имперскую Россию в 1809-1814 гг. Договариваясь о возможности его визита, президент ACLS Фредерик Буркхардт еще в апреле 1965 г. просил советскую администрацию в лице С. К. Романовского (председателя Госкомитета СССР по культурным связям с зарубежными странами) «помочь д-ру Баттерфилду в организации его встречи с советскими учеными и в разрешении доступа ему к соответствующим материалам» ${ }^{43}$.

К тому времени Баттерфилд уже успел прочитать статью Болховитинова о российской дипломатии и американской революции, которая была опубликована в английском переводе в нью-йоркской серии публикаций, редактировавшихся М. Е. Шарп [Болховитинов, 1964, с. 31-46]. Во время первой же встречи с чиновниками советской Академии наук профессор Баттерфилд сослался на Болховитинова как «на единственного всемирно известного советского специалиста по истории ранних российско-американских отношений, который проживает в Москве» ${ }^{44}$. После этого разговора представители международного отдела Института истории направили американского гостя к Болховитинову. Эти же чиновники присутствовали на встречах молодого советского американиста с профессором Баттерфилдом в различных московских архивах. Эти встречи стали незабываемым опытом для Болховитинова, который смог поделиться профессиональными открытиями с известным в своей области американским историком. Болховитинов по-настоящему наслаждался этими несколькими днями совместного сотрудничества с профессором Баттерфилдом. Впервые в своей жизни Болховитинов в процессе профессионального общения помогал американскому ученому найти архивные документы, относящиеся к визиту Джона Куинси Адамса в Россию, особенно «записки Адамса, которыми тот обменялся c [российским] канцлером Румянцевым, и всевозможные инструкции и депеши, посланные и полученные российским иностранным департаментом и его представителями в Соединенных Штатах»

Болховитинов был основной фигурой не только в процессе архивных поисков, но и при организации микрофильмирования советских

43 Письмо президента Американского совета научных сообществ Фредерика Буркхардта С. К. Романовскому от 19 апреля 1965 г. Папка «Переписка с Государственным комитетом по культурным связям с зарубежными странами» // Exchange agreements between the US and USSR, 1958-1968 // ACLS. F. 2. P. 789.

${ }^{44}$ Ibid., p. 11. p. 17].

${ }^{45}$ Интервью с Робертом Ивановым, Москва, 19 марта 1991 г. [Butterfield, Levin, 
архивных материалов для американского гостя. Будучи благодарным за эту помощь, по возвращению домой в США профессор Баттерфилд в ответ моментально организовал микрофильмирование всех документальных материалов из коллекции бумаг Адамса в Массачусетском историческом обществе, относящихся к Российской империи, и отправку этих пленок из Бостона в Москву для использования советскими исследователями. Николай Болховитинов оказался первым советским историком, который включил соответствующую информацию из этой коллекции в собственное исследование осенью 1965 г., когда первые пленки прибыли в Москву. На всю последующую жизнь Болховитинов сохранил добрую память о своем личном академическом обмене с американским историком, о том опыте, который повлиял на его исследовательские интересы и на его понимание добросовестного исторического исследования. Как он отметил позднее: «Для всей моей жизни профессор Баттерфилд оказался живым символом порядочного и профессионально компетентного западного историка» ${ }^{46}$.

Эта встреча с американским ученым привела к первому столкновению Болховитинова с офицерами КГБ из международного отдела Института истории. Еще в начале 1965 г. они вызвали Болховитинова в отдел по поводу «особого письменного запроса профессора Баттерфилда о его плане встречи с определенным советским исследователем Николаем Болховитиновым» в Москве. Один из этих офицеров инструктировал Болховитинова, «что делать и как вести себя с американским гостем». Офицер напомнил ему о необходимости «специального донесения обо всех разговорах», которое Болховитинов должен был предоставить в отдел немедленно после встреч с иностранным гостем («два дня максимум»). Вынужденно следуя рекомендациям офицера КГБ, Болховитинов в мае 1965 г. докладывал о «(1) биографии и научной деятельности профессора Баттерфилда, (2) темах обсуждаемых вопросов и разговоров во время встреч с этим американским гостем и (3) различных мыслях, предложениях, советах и пожеланиях, высказываемых профессором Баттерфилдом» ${ }^{47}$. Вся эта контролируемая процедура встреч с профессором Баттерфилдом и последующих контактов с КГБ оставила у Болховитинова самые негативные впечатления.

Можно отметить несомненное влияние на все советское общество той поры американской массовой культуры, и прежде всего «неожиданный наплыв» американского кино в московских кинотеатрах в течение 1964-1966 гг. [Raleigh, p. 133-135]. Николай Болховитинов и его коллеги-американисты, такие как Николай Сивачев и Роберт Иванов, заметили, что в этот период новые американские кинокартины демонстрировались по всей Москве. Более того, как вспоминал Болховитинов позднее, в течение той же весны 1965 г. он и несколько советских экспертов по американской политике и культуре и многочисленные советские ученые были приглашены чиновниками Цен-

\footnotetext{
${ }^{46}$ Интервью с Н. Н. Болховитиновым, Москва, 12 июня 1991 г.

47 Это было типичным требованием КГБ [Черкасов, с. 315].
} 
трального комитета КПСС для специального закрытого просмотра двух американских антивоенных фильмов, чтобы решить, насколько они приемлемы для советской публики. Один из них был картиной Стенли Крамера «На берегу» (1959), а другой - британо-американским фильмом «Доктор Стренджлав» (1964), поставленным Стэнли Кубриком. Хотя все советские американисты, посетившие просмотр, рекомендовали разрешить фильмы для демонстрации в широком прокате, эти картины никогда не были показаны в Советском Союзе как «чрезмерно устрашающие нормального советского зрителя наглядными результатами ядерной войны» [English, p. 106], хотя иные, «менее устрашающие» фильмы, «сделанные в США», вышли на экраны всех основных кинотеатров Москвы ${ }^{48}$. На Московском кинофестивале летом 1965 г. был организован официальный показ американского кино, на который были приглашены звезды Голливуда, такие как Стив Маккуин (любимец поклонников американского вестерна «Великолепная семерка») и Кэрролл Бэйкер, которые встречались с советской публикой и давали многочисленные интервью советским журналистам ${ }^{49}$. Используя личные связи своего отца в Академии наук СССР, Николай Болховитинов достал несколько билетов на конкурсные просмотры фестивальных фильмов с 6 по 20 июля 1965 г. $^{50}$ Согласно его реакции после просмотра американских фильмов на московском фестивале, он был сильно разочарован низким качеством американских «коммерческих кинокартин», показанных в Москве $\mathrm{M}^{51}$. Как отметил Болховитинов, для него это было «очередным разочарованием, связанным со страной», которая стала объектом его академических интересов.

Насколько я помню, убийство Кеннеди в 1963 г. было моим первым настоящим разочарованием, которое разрушило мои прежние иллюзии о США. И опять этот глупый комедийный фильм Блэйка Эдвардса об автомобильной гонке Нью-Йорк - Париж 1908 г. с такими талантливыми актерами как Джек Леммон, Тони Куртис и Натали Вуд продемонстрировал то, как американский режиссер, потакая низким вкусам публики, движимый желанием заработать больше денег и привлечь зрителей, в итоге коммерчески убивает кинематографическое искусство. По сравнению с серьезными американскими картинами, представленными на московском фестивале, такими как «Убить пересмешника» и «Скованные одной цепью»

${ }^{48}$ Интервью с Н. Н. Болховитиновым, Москва, 10 июля 2004 г. Ср.: [ English, p. 106].

${ }^{49}$ О популярности американского кино в Москве в 1964 и 1965 г. см.: [Карцева, c. 16; Советский экран, 1965, № 13, 24 и обложка № 14]. Сp.: [Roth-Ey, p. 115-120].

${ }^{50}$ См.: [Советский экран, № 16, с. 1,6].

${ }^{51}$ Письмо Н. Н. Болховитинова, Москва, 29 января 1997 г.: «После просмотра таких талантливых и серьезных картин, как "На берегу" и т. п., мы испытали естественный шок от очевидного коммерческого характера недавних фильмов, представленных американскими гостями на московском фестивале... Мы не могли понять, как можно было награждать такую жалкую поделку, как американская комедия "Большие гонки"». Ср.: [Советский экран, № 16, с. 1]. 
(The Defiant Ones), «Большие гонки» стали моим следующим разочарованием по поводу Америки, поскольку этот фильм еще раз подтвердил мое мнение о чисто развлекательном и коммерческом характере американской культуры. Парадоксально, но все эти мои наблюдения не только вписывались в советские идеологические клише об американской капиталистической цивилизации, но и способствовали формированию моего скептического отношения к западному капитализму ${ }^{52}$.

\section{Научная повседневность советских американистов}

Начиная с 1960-х гг. вся жизнь Болховитинова полностью зависела от академической политики Института истории (после 1968 г. - Института всеобщей истории) Академии наук СССР. Все академические практики этого института оставались неизменными и после свержения Хрущева. Многие коллеги Болховитинова из Института истории подтверждали, что «ничего не изменилось коренным образом» в рутине их академической жизни после 1964 г. ${ }^{53}$ Они по-прежнему имели только два рабочих, так называемых присутственных дня (обычно в понедельник и среду), когда они посещали свои кабинеты в институте всего на несколько часов. На самом деле советские ученые, работающие в академических институтах, таких, как Институт истории, должны были посещать официальные заседания только раз в неделю (обычно по средам). Все остальные дни недели назывались «библиотечными днями», когда институтские сотрудники должны были проводить исследовательскую работу в архивах или библиотеках ${ }^{54}$. Система присутственных дней существовала во всех институтах советской Академии наук, особенно в Москве. Вот так описывала подобную систему работы в Институте США и Канады в 1970-е гг. другая современница событий Галина Орионова:

Главный рабочий день был присутственный день в Институте США и Канады. В разных академических институтах эти дни выбирались поразному. В моем институте это были понедельник, среда и пятница. Мы знали, что Арбатов (директор Института США и Канады) появляется на работе обычно после обеда... или где-то после трех часов дня. Поэтому мы тоже появлялись на работе обычно после трех... В Институте международного рабочего движения было лучше: они имели только два присутственных дня - вторник и пятницу... Поэтому многие исследователи делали свою работу дома. Никто, конечно, не следовал установленным правилам работать в библиотеках [op. cit.: Dash, c. 198, 199].

По сравнению с тяжелой преподавательской нагрузкой и служебными обязанностями в провинциальных учебных институтах и уни-

\footnotetext{
${ }^{52}$ Интервью с Н. Н. Болховитиновым, Москва, 21 мая 2001 г.

${ }^{53}$ См. мемуары коллег Болховитинова: [Nekrich, p. 179-244; Гутнова, с. 258-271, 274-279; Гуревич, с. 208-239].

${ }^{54}$ Интервью с Мариной Власовой, Вадимом Коленеко, Сергеем Буриным, Москва, 20 февраля 1996 г.; электронное письмо Владислава Зубока, 27 мая 2013 г.
} 
верситетах, работа в академических институтах столицы считалась «большой привилегией, научным раем» или, как позднее Александр Фурсенко назвал это явление, «академической синекурой» ${ }^{55}$. Нормальная преподавательская нагрузка профессора истории в МГУ включала два-три общих или специальных курса в семестр, а средняя нагрузка в провинциальном советском университете в Днепропетровске и Одессе была четыре-шесть курсов в семестр ${ }^{56}$.

Болховитинов и сам признавал, что он и его коллеги из академических институтов имели гораздо более комфортные условия для исследовательской работы, чем преподаватели в советских вузах. Как он объяснял впоследствии:

В течение 1964-1966 годов в среднем я проводил шесть-восемь часов ежедневно в библиотеке или дома, чтобы написать или переписать свой материал, вначале для моей докторской диссертации, а затем для моей книги. Честно говоря, я появлялся в институте один раз в неделю, иногда даже один раз в две недели. У меня было много времени для сна, отдыха и осмысления того материала, который я исследовал и описывал ${ }^{57}$.

Используя свое свободное время продуктивно, Болховитинов подготовил для публикации целую серию научных статей, которые стали главами докторской диссертации, которую он защитил в 1965 г. ${ }^{58}$

В конце января 1966 г. Болховитинов начал подготовку докторской диссертации для публикации. Объем рукописи в два раза превышал официальные требования, предъявляемые к изданию научных книг академическим издательством «Наука». Противники Болховитинова пытались приостановить публикацию его рукописи в престижном академическом издательстве, но постоянная настойчивая поддержка его научного руководителя и коллеги Алексея Ефимова спасла рукопись. В итоге под давлением Ефимова редакторы «Науки» даже согласились с запредельными размерами рукописи. Это был самый счастливый период творческой жизни Болховитинова в Отечестве. Как он заметил позже, «весна 1966 г. был самым счастливым временем моей жизни; никто не мешал мне готовить мой текст публикации; все мои исправления были приняты без возражений» [Болховитинов, б. г., с. 46, 47] ${ }^{59}$.

Даже его личный недруг и ветеран разведки КГБ Г. Севостьянов вдруг перестал докучать ему своей критикой и нападками. Севостьянов

\footnotetext{
${ }^{55}$ Интервью с Александром Фурсенко, Москва, 19 марта 1991 г.

${ }^{56}$ Интервью с Виктором Калашниковым и Александром Михайлюком (Днепропетровск, 20 марта 1992 г.) и с Мариной Власовой, Москва, 26 марта 1992 г.

${ }^{57}$ Интервью с Николаем Болховитиновым, Москва, 21 мая 2001 г.

${ }^{58}$ На протяжении 1965 г. его публикации появились в различных изданиях [Болховитинов, 1964а, с. 203-239; Он же, 19646, с. 73-88; Болховитинов, Семенов, с. 389415; Болховитинов, 1965a, с. 153-159; Он же, 19656, с. 102-113].

${ }^{59}$ Интервью с Н. Н. Болховитиновым, Москва, 10 июля 2004 г. И Роберт Иванов, и Игорь Дементьев подтвердили существование анти-Болховитиновских интриг в издательстве.
} 
неожиданно восстановил дружественные отношения с молодымученым и стал всячески поддерживать его изыскания. Как выяснилось после 1966 г., Севостьянов пытался создать коалицию своих сторонников в секторе истории США, планируя сменить прежнего главу этого сектора Бориса Михайлова. В этой борьбе за власть в предстоящих выборах нового руководителя сектора Севостьянов искал поддержки Болховитинова. Вследствие этого в течение двух лет Болховитинов имел «лучшие, чем когда либо, условия для работы в секторе» и «удивительно дружеские отношения с Севостьяновым» ${ }^{60}$.

Публикация книги в июне 1966 г. сделала Болховитинова новой молодой восходящей звездой советской американистики. Он стал известен как самый молодой исследователь американской истории в Советском Союзе, который уже опубликовал две монографии, послужившие основанием для очень серьезного, основанного на скрупулезном анализе документов исследования истории США XVIII-XIX вв. и начала российско-американских отношений. Как впоследствии заметил один из коллег Болховитинова, публикация этой новой книги означала «появление феномена Болховитинова в советской историографии» [Комиссаров, с. 16].

Профессор Илья Саввич Галкин, заведующий кафедрой новой и новейшей истории МГУ, пригласил Николая Болховитинова читать лекции для преподавателей и студентов университета. В начале 1967 г. он попросил Болховитинова написать рецензию на новый учебник по историографии новой и новейшей истории Европы и Америки, подготовленный коллегами Галкина из МГУ ${ }^{61}$. Более того, Галкин, которому искренне нравился этот молодой талантливый ученый, даже пообещал ему ставку профессора истории по совместительству на кафедре новой и новейшей истории МГУ [Болховитинов, б. г., с. 47-48] ${ }^{62}$.

Но некоторые из коллег-американистов с кафедры Галкина опасались иметь в качестве сослуживца успешного и талантливого историка, в котором они видели прежде всего конкурента. Один из них, бывший студент Галкина профессор Игорь Дементьев, начал открыто жаловаться, что его студенты предпочитают теперь этого «визитера» из Института истории. В результате этих постоянных жалоб Галкин вынужден был изменить условия договора с Болховитиновым, который остался на кафедре как лектор-почасовик без академического статуса профессора. На этих условиях Болховитинов преподавал в МГУ вплоть до 1974 г., иногда даже имея возможность руководить студентами-дипломниками [Там же] ${ }^{63}$.

\footnotetext{
${ }^{60}$ Интервью с Робертом Ивановым и Сергеем Буриным, Москва, 6 сентября 1998 г. Письмо Н. Н. Болховитинова, Москва, 29 января 1997 г.

${ }^{61}$ Эта большая рецензия была опубликована в 1969 г. в соавторстве с В. А. Дунаевским в журнале «Вопросы истории» (1969. № 7. С. 151-155).

${ }^{62}$ Биографию И. С. Галкина см.: [Дементьев]; см. также мемуары И. С. Галкина [Галкин].

${ }^{63}$ Галкин старался противостоять многочисленным интригам против Болховитинова. См. об этом: [Архив МГУ. Ф. 9. Оп. 8. Д. 962 Л. 14-22].
} 
Как впоследствии вспоминал Болховитинов, 1968 г. был наиболее удачным в плане его личной жизни и академической карьеры. Вопервых, в течение этого года Институт истории был разделен на два Институт истории СССР и Институт всеобей истории. Сектор американских стран превратился в сектор истории США и Канады, который был переведен в Институт всеобщей истории. Уже будучи сотрудником этого сектора, Болховитинов, к тому времени защитивший докторскую диссертацию, получил должность старшего научного сотрудника. Несмотря на такое продвижение по службе, Болховитинов был разочарован, поскольку он утратил непосредственные контакты с серьезными исследователями российской дореволюционной истории, такими как А. А. Зимин, В. Т. Пашуто и А. А. Преображенский, с теми учеными, которые вдохновили его недавно на его собственные архивные изыскания и которые переехали теперь в новый Институт истории СССР ${ }^{64}$.

Главным же лицом, начавшим реорганизацию Института истории в 1968 г., был старый друг Леонида Брежнева Сергей Павлович Трапезников, с 1948 г. работавший с ним в Молдавии в качестве директора Высшей партийной школы. Впоследствии Брежнев перевел Трапезникова в Москву, где тот сделал неплохую карьеру, в 1966 г. был избран членом ЦК КПСС и главой отдела науки и учебных заведений в том же самом ЦК. В 1966 г. Трапезников попытался стать действительным членом Академии наук СССР. К чести советской академии, большинство ее членов проголосовали против его кандидатуры. В результате униженный Трапезников решил отомстить академикам [Медведев, с. 64-65, 143-145]. Другим основанием для разделения института послужила решительная позиция институтского парткома, который категорически отверг официальное решение ЦК КПСС об исключении историка Александра Некрича из партии за критику советского руководства в период Второй мировой войны, которую он выразил в своей книге о начале Великой Отечественной войны [Болховитинов, 1997, с. 73; см. также: Markwick, 203ff.].

Если согласиться с мнением А. Некрича, то насильственное разделение «свободомыслящего» Института истории в 1968 г. было своего рода местью Трапезникова ученым, которые открыто критиковали низкие интеллектуальные способности и «отсутствие академических данных этого партийного аппаратчика», официально специализировавшегося в сфере «советской аграрной истории» [Nekrich, p. 221]. В качестве «эксперта» по советской истории он попытался создать особый Институт истории СССР, который бы подчинялся его приказам, предварительно убрав из состава его сотрудников своих потенциальных соперников - настоящих специалистов по советской истории. В результате подобных маневров Трапезникова Институт истории СССР стал более консервативным, «сдав академическое ли-

${ }^{64}$ Как писал в своих мемуарах Александр Некрич, «указом секретариата Центрального Комитета и президиума Академии наук Институт истории был разделен на два: Институт истории СССР и Институт мировой истории» («процесс реорганизации длился год...») [Nekrich, p. 221]. 
дерство Институту всеобщей истории, состав которого оставался все еще непредвзятым, открытым ко всем прогрессивным влияниям и готовым к диалогу с западными историками» ${ }^{65}$.

Тем временем в 1968 г. старый недруг Болховитинова Севостьянов выиграл борьбу за власть в секторе американской истории и стал его главой, коренным образом изменив природу руководства данного подразделения института, исполняющим обязанности которого он был назначен в сентябре 1967 г. Вместо контроля со стороны ЦК КПСС, осуществлявшегося прежним руководителем сектора Борисом Михайловым, специалистом по истории международного рабочего класса, бывший советский разведчик и офицер КГБ Григорий Севостьянов перенес на этот сектор прямой контроль КГБ. В конечном итоге в апреле 1969 г. назначение Севостьянова заведующим нового сектора истории США и Канады было окончательно одобрено администрацией Института всеобщей истории ${ }^{66}$. В первые годы своего руководства Севостьянов относился к Болховитинову как к своему союзнику и поддерживал его академическую карьеру. Когда же Болховитинов напомнил Севостьянову о необходимости своей поездки в США, чтобы продолжить исследование в американских архивах и библиотеках, Севостьянов открыто поддержал просьбу Болховитинова о научной командировке и организовал специальное собрание их сектора, чтобы обсудить так называемый научный план Болховитинова для его предстоящей исследовательской поездки за рубеж. Правда, как выяснилось позже, в 1966 и 1967 г. Севостьянов, «расхваливавший на людях академические достижения Болховитинова», в то же время всячески препятствовал продвижению его документов на выезд в США и отказывался поддерживать его в разговорах с администрацией из международного («первого») отдела института [Болховитинов, б. г., с. 46] ${ }^{67}$.

\section{8 г.: первая поездка Болховитинова в Америку}

Несмотря на тайные интриги и возражения Севостьянова, международный отдел все-таки одобрил запрос Болховитинова о его научной командировке за рубеж в январе 1968 г. Болховитинов считает, что эта первая в его жизни научная командировка в Соединенные Штаты стала

${ }^{65}$ Интервью с Робертом Ивановым, Москва, 6 сентября 1998 г.

${ }^{66}$ В официальных советских публикациях выражалось открытое восхищение профессиональным прошлым Севостьянова как выдающегося советского разведчика и офицера КГБ перед началом его академической карьеры в 1950 г. Такую информацию можно было найти в рубрике Научная жизнь в издании Американского ежегодника времен перестройки [Бурин, с. 211-215]. После своей «шпионской карьеры» вначале в Белоруссии, а затем на Дальнем Востоке во время и после Второй мировой войны в 1947 г. Севостьянов был послан КГБ в Высшую дипломатическую школу Министерства иностранных дел СССР, которую он закончил, защитив диссертацию в 1950 г., и был рекомендован КГБ для трудоустройства в Институте истории. В 1960 г. он защитил докторскую диссертацию и был назначен в сентябре 1967 г. исполняющим обязанности главы сектора истории США и Канады. См. также: [Новые члены Академии наук СССР; Григорий Николаевич Севостьянов].

${ }^{67}$ Роберт Иванов также подтвердил этот факт (интервью с Робертом Ивановым и Вадимом Коленеко, Москва, 6 сентября 1998 г.). 
самым важным событием 1968 г. В результате командировки Болховитинов не только нашел в американских архивах и научных библиотеках новые документы и литературу об истории ранних американо-российских отношений, но и установил свои собственные личные контакты с американскими экспертами в области американской истории и истории дипломатии. Во время посещения Америки Болховитинов жадно впитывал новую и по форме, и по содержанию информацию о событиях в его собственной стране и во всем социалистическом блоке, информацию, которая была доступна через различные формы американских масс-медиа. И наконец, этот первый (и самый длительный) визит в США открыл Болховитинову новые стороны американской повседневной жизни и американской культуры, что позволило ему полностью избавиться от «предубеждений и скептических настроений по поводу американской действительности» ${ }^{68}$.

Болховитинов подавал запросы на поездку в США начиная с 1959 г., когда первые слухи о советско-американских соглашениях по поводу академических обменов достигли его коллег в Институте истории. Некоторые американисты из МГУ и из его собственного «американского» сектора, такие как Николай Сивачев и Ирина Белявская, уже регулярно путешествовали на Запад, особенно в Америку, используя правила тех же советско-американских соглашений ${ }^{69}$.

В 1960 г. после многочисленных безуспешных попыток подать заявку на научную командировку за рубеж Болховитинов решился подойти к работникам международного отдела института и спросил у них совета о том, «что делать, чтобы запросы о поездке в США завершились успехом». Эти чиновники, напрямую связанные с КГБ, посоветовали ему, во-первых, стать членом партии, а затем подать заявку на туристическую поездку в социалистические страны Европы, чтобы продемонстрировать «свое идеологически правильное поведение в время путешествия за рубежом». Они также напомнили ему, что он должен будет заполнять специальную форму для разрешения на зарубежную поездку, так называемую справку-объективку, которая бы не только освещала детали его автобиографии, но и содержала информацию об аресте его отца в 1930-е гг., а также о его предыдущих личных контактах с иностранцами ${ }^{70}$. Болховитинов последовал этим рекомендациям, вступил в Коммунистическую партию в 1961 г., а затем оформил документы на турпоездку в социалистическую Чехословакию, которую и посетил в 1963 г. в составе специальной туристической группы представителей Академии наук ${ }^{71}$. Как признавался сам Болховитинов, его

${ }^{68}$ Интервью с Н. Н. Болховитиновым, Москва, 12 июня 1991 г.

${ }^{69}$ См. документы о поездках в США коллег Болховитинова Ирины Белявской, Виктора Малькова, Бориса Михайлова и Григория Севостьянова в 1962-1963 гг. в американских документах [Exchange agreements between the US and USSR, 19581968 // ACLS. F. 2. P. 789; Programs of Exchanges of Scholars in the Humanities and Social Sciences between the ACLS and the Academy of Sciences of the USSR (Revised on 11.19.1968), page 2 // ACLS. F. 2. P. 2].

${ }^{70}$ Cм.: [Dash, p. 11-12, Черкасов, с. 216, ссылка 2].

${ }^{71}$ Интервью с Н. Н. Болховитиновым, 10 июля 2004 г. 
«открытие капиталистического Запада» началось с визитов в такие социалистические страны, как Чехословакия в 1963 г. и Польша, Венгрия и Болгария в 1966 г. Наиболее яркое впечатление на него произвел уровень «открытости западным капиталистическим влияниям» в восточноевропейских социалистических странах по сравнению с закрытостью советского общества. Болховитинов также вспоминал не только некоторые образцы западных масс-медиа, таких как британские и западногерманские журналы в киосках восточноевропейских городов, но и «полностью отличные от нашего советского стиля ментальность и восприятие внешнего мира среди восточноевропейских интеллектуалов, включая местных историков» ${ }^{72}$.

«Более того, - вспоминал Болховитинов, - я начинал завидовать восточноевропейскому уровню свободы и тому, как наши социалистические коллеги из соседних стран Восточной Европы могли легко контактировать с западными интеллектуалами, особенно с учеными из Соединенных Штатов Америки» ${ }^{73}$. Многие коллеги Болховитинова тоже вспоминали, как их вдохновляло личное общение с историками из стран социалистического лагеря. Так, Арон Гуревич, известный советский историк-медиевист, коллега Болховитинова из того же Института истории, вспоминал в своих мемуарах о своей первой туристической поездке за рубеж в социалистическую Польшу в 1967 г., о своих разговорах и спорах с польскими историками, такими как Станислав Пекарчик, который пригласил его посетить Варшаву, о том, как эти разговоры открыли для него новые интеллектуальные горизонты. Находясь под влиянием французских ученых, представителей школы Анналов, которые за год до приезда Гуревича посетили Польшу и прочитали там лекции о своих теоретических подходах, его польские коллеги поделились с ним своим искренним восхищением перед современной французской историографией и восторгами по поводу «западной свободы выражения и исторического воображения». Его польские друзья так шутили по поводу своей жизни в социалистическом лагере: «Да, и вы в СССР, и мы в Польше живем в одном и том же социалистическом лагере, но жизнь в нашем польском лагерном бараке значительно веселее, чем в вашем советском бараке» [Гуревич, с. 187].

После каждой своей поездки в восточноевропейские страны Николай Болховитинов продолжал регулярно заходить в международный отдел Института истории, напоминая его работникам о своих намерениях посетить США. И однажды в ноябре 1967 г., к удивлению Болховитинова, ему сообщили об одной открытой вакансии в списке кандидатов на научную командировку в капиталистические страны. По свидетельству современников, которые имели длительные связи с международным («первым») отделом Института истории, «различные ассистенты Центрального комитета КПСС поддержали кан-

\footnotetext{
72 Письмо Н. Н. Болховитинова, Москва, 29 января 1997 г. О понятии открытости советского общества после Сталина см.: [Zhuk, 2011].

${ }^{73}$ Письмо Н. Н. Болховитинова, Москва, 29 января 1997 г.
} 
дидатуру Болховитинова для зарубежной командировки в Америку, аргументируя тем, что он являлся уникальным экспертом в истории российско-американских отношений, и его знания и опыт помогут советским дипломатам правильно интерпретировать решения американских политиков и дипломатов» ${ }^{74}$.

В начале декабря 1967 г. после частых визитов в международный отдел и предоставления его работникам всех необходимых бумаг для выезда за рубеж, включая официальные характеристики от институтских организаций компартии и профсоюзов, Болховитинов наконецто был официально утвержден как кандидат на научную командировку на шесть месяцев в США в качестве участника академического обмена в рамках совместной программы Американского совета ученых обществ (ACLS) и Академии наук CCCP. Согласно документам ACLS, советские организаторы обмена все еще сомневались в правильности своего выбора, сохраняя заявку не заполненной в течение года вплоть до ноября 1967 г., когда кандидатура Болховитинова была наконец-то одобрена, и информация о нем была отправлена в Америку письмом с припиской: «это советский участник обмена - историк, не включенный в первоначальный список» ${ }^{75}$. Только 7 декабря 1967 г. ACLS дал официальное подтверждение на полугодовую поездку Болховитинова в США. 31 декабря 1967 г. американская сторона послала свой список советских участников академического обмена, включив в него имя Болховитинова, на утверждение в Министерство иностранных дел СССР, которое официально разрешило ему въезд в США с февраля по август 1968 г. $^{76}$

За несколько недель до поездки в январе 1968 г. Болховитинову неожиданно позвонили из международного отдела института о необходимости «особого разговора со специалистами по зарубежным поездкам об инструкциях для отправляющихся в международные научные командировки». Когда Болховитинов зашел в международный

74 Бывший коллега Н. Н. Болховитинова американист-историк Иван Краснов жаловался, что «имя Болховитинова особенно подчеркивалось людьми из окружения Аджубея из Центрального Комитета, которые открыто поддерживали кандидатуру Болховитинова» (из интервью с Вадимом Коленеко, Робертом Ивановым и Мариной Власовой в Институте всеобеей истории, Москва, 21 марта 1991 г.). Отец Власовой работал в аппарате ЦК КПСС. Используя эти связи, Марина Власова пригласила Болховитинова в качестве оппонента на защиту своей кандидатской диссертации в 1986 г.

${ }^{75}$ Programs of Exchanges of Scholars in the Humanities and Social Sciences between the ACLS and the Academy of Sciences of the USSR [ACLS. Exchanges in 1966-1967 for 1968. P. 5. F. 2. P. 789: Exchange agreements between the US and USSR, 1958-1968].

${ }_{76}$ Интервью с Н. Н. Болховитиновым 10 июля 2004 г.; [Болховитинов, с. 47; Butterfield, Levin, p. 18]. Cp.: [Exchange agreements between the US and USSR, 1958-1968 // ACLS. F. 2. P. 789; Library of Congress, Manuscript Collection, Folder "Administration of IIE [Institute of International Education (New York)]; письмо от Шарлотты Бауман, административного секретаря Американского совета по научным обществам, к миссис Энн Доэрти (Институт международного образования) от 7 декабря 1967 г. : «я прикрепляю копию перевода письма от Академии наук СССР, датированного 11 ноября, но полученного только недавно, в котором Н. Н. Болховитинова называют претендентом на полугодовую командировку» (мы не стали переводить последние две страницы - биографию господина Болховитинова). 
отдел, ему сразу же представили молодого человека, назвавшегося «экспертом по загранпоездкам». После достаточно длительного разговора о будущих исследовательских планах в период командировки Болховитинова в США этот «эксперт» предложил Николаю продолжить «этот интересный разговор» в «неофициальной атмосфере». Он дал адрес своей квартиры и попросил Болховитинова прийти туда на следующий день. Как впоследствии рассказывал Болховитинов, эта квартира в самом центре Москвы служила местом секретных встреч для КГБ, а «эксперт по загранпоездкам» был его сотрудником. Во время следующей встречи этот офицер, не церемонясь, напрямую предложил Болховитинову сотрудничество с КГБ и «вежливо попросил» Болховитинова периодически пересылать ему «специальную информацию» во время его командировки в Америку. Находясь в состоянии шока от такого предложения, Болховитинов не нашелся, что ответить, а затем решил, по его собственному выражению, «играть дурака ${ }^{77}$. После кратковременной паузы Болховитинов пообещал, что он подумает об этом предложении и затем свяжется с ним по особому телефонному номеру, который тот ему дал. В результате он так и не позвонил и старался избегать новых встреч, находя на то различные причины. Больше всего он боялся того, что его отказ от сотрудничества с КГБ приведет к запрету на поездку в США. К величайшему его удивлению, тот же самый офицер посетил его дома за несколько дней до его отъезда в Соединенные Штаты. Перепуганный Болховитинов пригласил офицера на чашку чая и после длительной беседы был вынужден пообещать встретиться с ним непосредственно перед поездкой, чтобы продолжить «переговоры». Тем временем, как Болховитинов объяснил позднее, он «был настолько занят упаковкой вещей и ментальной подготовкой перед поездкой, что у него просто не было времени для последующей встречи и продолжения серьезного разговора» ${ }^{78}$. До последней минуты, вплоть до посадки его самолета в Нью-Йорке в феврале 1968 г. он боялся, что его «снимут с самолета и не позволят больше летать в США люди из КГБ» ${ }^{79}$.

\section{Список литературы}

Архив Московского государственного университета (МГУ). Ф. 9. Оп. 8. Д. 962.

Болховитинов Н. Личная переписка: 1987-1997 гг. (Письма, адресованные автору, находятся в его личном архиве).

Болховитинов Н. Н. Становление русско-американских отношений, 1775-1815. М. : Наука, 1966. 638 с.

Болховитинов Н. Н. К вопросу о позиции США в войне Латинской Америки за независимость // Война за независимость в Латинской Америке (1810-1826) / под ред. Н. М. Лаврова. М. : Наука, 1964. С. 203-239.

Болховитинов Н. Н. Русская дипломатия и война США за независимость 17751783 годов // Новая и новейшая история. 1964. № 1. С. 73-88.

${ }^{77}$ Интервью с Н. Н. Болховитиновым, Москва, 10 июля 2004 г.

${ }_{78}^{7}$ Там же.

79 Я цитирую интервью от 10 июля 2004 г. и его воспоминания [Болховитинов, б. г., с. 49-50]. 
Болховитинов Н. Н., Семенов С. И. От «доктрины Монро» к «Союзу ради прогресса» / под ред. И. М. Лемина. М. : Наука, 1965. С. 389-415.

Болховитинов Н. Н. Война Латинской Америки за независимость и позиция России // Вопр. истории. 1965. № 11. С. 153-159.

Болховитинов Н. Н. Становление научных и культурных связей между Америкой и Россией // История СССР. 1965. № 5. С. 102-113.

Болховитинов Н. Н. В архивах и библиотеках США: находки, встречи, впечатления //Американский ежегодник. 1971. М. : Наука, 1971. С. 329-341.

Болховитинов Н. Н. О времени и о себе: заметки историка // Историки России. Вып. 1. М. : Наука, 1997. С. 70-79.

Болховитинов Н. Н. Воспоминания [М., б. г.]. [отпечатанная на машинке рукопись, 62 страницы, которая начинается фразой «Счастливая пора детства»] (Оригинал находится у вдовы Н. Н. Болховитинова Людмилы Антоновны Болховитиновой. Автор использовал свою копию оригинала).

Бурин С. Н. К 75-летию академика Г. Н. Севостьянова // Американский ежегодник. 1990. М. : Наука, 1991. С. 211-215.

Галкин И. С. Тропами моей жизни : На посту ректора МГУ // Новая и новейшая история. 1998. № 4. С. 90-112; № 5. С. 111-132.

Григорий Николаевич Севостьянов : [некролог] // Новая и новейшая история. 2013. № 3. С. 245-248.

Гуревич А. История историка. М. : РОССПЭН, 2004. 284 с.

Гутнова Е. В. Пережитое. М. : РОССПЭН, 2001. 462 с.

Дементьев И. П. Илья Саввич Галкин // Портреты историков : Время и судьбы / отв. ред. Г. Н. Севостьянов. М. : Наука, 2004. Т. 4. Новая и новейшая история. С. 105-123.

Кариева Е. Что человеку надо // Советский экран. 1965. № 2. С. 16.

Комиссаров Б. Н. Ас отечественной американистики (к 70-летию Н. Н. Болховитинова) // Русское открытие Америки : сб. ст., посв. 70-летию академика Николая Николаевича Болховитинова / под ред. А. О. Чубарьяна. М. : РОССПЭН, 2002. С. 5-36.

Медведев Р. Личность и эпоха : Политический портрет Л. И. Брежнева. М. : Новости, 1991.

Новые члены Академии наук СССР // Вестник Академии наук СССР. М., 1988. Вып. 2. С. 123-126.

Познер В. В. Прощание с иллюзиями. М. : АСТ, 2013. 478 с.

Черкасов П. ИМЭМО. Институт мировой экономики и международных отношений : Портрет на фоне эпохи. М. : Весь мир, 2004.

Arbatov G. The System: An Insider's Life in Soviet Politics. N. Y. : Random House, 1992. $380 \mathrm{p}$.

Butterfield L. H. Introduction // Bolkhovitinov N. N. The Beginnings of Russian-American Relations, 1775-1815 / transl. by E. Levin. Cambridge ; Mass., Harvard University Press, 1975. P. 10-18.

Dash B. L. A Defector Reports: The Institute of the USA and Canada. Falls Church, VA, Delphic Associates, 1982.

English R. Russia and Idea of the West: Gorbachev, Intellectuals, and the End of the Cold War. N. Y. : Columbia University Press, 2000. 401 p.

Kurilla I. Russian/Soviet Studies in the United States, Amerikanistika in Russia: Mutual Representations in Academic Projects / ed. by V. I. Zhuravleva. Lanham, MD and Boulder ; CO, Rowman and Littlefield's Lexington Press, 2015. 306 p.

Markwick R. D. Rewriting History in Soviet Russia: The Politics of Revisionist Historiography, 1956-1974 / Raleigh D. J. (Foreword). N. Y. : Palgrave, 2001. 327 p.

Nekrich A. Forsake Fear: Memoirs of an Historian / transl. by D. Lineburgh. Boston : Unwin Hyman, 1991. 293 p.

Raleigh D. J. Soviet Baby Boomers: An Oral History of Russia's Cold War Generation. N. Y. : Oxford University Press, 2012. 420 p.

Roth-Ey K. Moscow Prime Time: How the Soviet Union Built the Media Empire That Lost the Cultural Cold War. Ithaca: Cornell University Press, 2011. 315 p.

Zhuk S. Closing and Opening Soviet Society (Introduction to the Forum Closed City, Closed Economy, Closed Society: The Utopian Normalization of Autarky) // Ab Imperio. 2011. № 2. P. 123-158.

Zhuk S. I. 'Academic Détente': IREX Files, Academic Reports, and 'American' Adventures of Soviet Americanists during the Brezhnev Era // Cahiers du monde russe. 2013a. Vol. 54. No. 1-2. P. 297-328. 
Zhuk S. I. Inventing America on the Borders of Socialist Imagination: Movies and Music from the USA and the Origins of American Studies in the USSR // Region: Regional Studies of Russia, Eastern Europe, and Central Asia. 2013b. Vol. 2. No. 2. P. 249-288.

\section{References}

Arbatov, G. (1992). The System: An Insider's Life in Soviet Politics. 380 p. New York, Random House.

Arkhiv Moskovskogo gosudarstvennogo universiteta [Moscow State University Archive]. Stock 9 (Kafedra novoy i noveyshey istorii, mezhdunarodnye svyazi). List 8. Dossier 962.

Bolkhovitinov, N. (n.d.). Lichnaya perepiska: 1987-1997 gg. [Personal Correspondence: 1987-1997]. (Pis'ma, adresovannye avtoru, nakhodyatsya v lichnoy kollektsii avtora).

Bolkhovitinov, N. N. (1966). Stanovlenie russko-amerikanskikh otnosheny, 1775-1815 [The Beginning of Russian-American Relations, 1775-1815]. 638 p. Moscow, Nauka.

Bolkhovitinov, N. N. (1964). K voprosu o pozitsii SShA v voyne Latinskoy Ameriki za nezavisimost' [About US Position in the War of Independence in Latin America]. In Lavrov, N. M. (Ed.) Voyna za nezavisimost' $v$ Latinskoy Amerike (1810-1826) (pp. 203-239). Moscow, Nauka.

Bolkhovitinov, N. N. (1964). Russkaya diplomatiya i voyna SShA za nezavisimost', 1775-1783 godov [Russian Diplomacy and US War of Independence, 1775-1783]. In Novaya i noveyshaya istoriya, 1 , pp. 73-88.

Bolkhovitinov, N. N. (1964). Russian Diplomacy and the US War for Independence of 1775-1783. In Soviet Studies in History, Vol. 3, No. 2, pp. 31-46.

Bolkhovitinov, N. N. \& Semenov, S. I. (1965). Ot "doktriny Monro" k "Soyuzu radi progressa" [From Monroe Doctrine to the Alliance for Progress]. In Lemin, I. M. Dvizhushchie sily vneshnei politiki SSHA (pp. 389-415). Moscow, Nauka.

Bolkhovitinov, N. N. (1965). Voyna Latinskoy Ameriki za nezavisimost' i pozitsiya Rossii [Latin American War of Independence and Russian Position]. In Voprosy istorii, 11, pp. 153-159.

Bolkhovitinov, N. N. (1965). Stanovlenie nauchnykh i kul'turnykh svyazey mezhdu Amerikoy i Rossiey [The Beginning of Scientific and Cultural Relations between America and Russia]. In Istoriya SSSR, 5, pp. 102-113.

Bolkhovitinov, N. N. (1971). V arkhivakh i bibliotekakh SShA: nakhodki, vstrechi, vpechatleniya [In US Archives and Libraries: Findings, Meetings, Impressions]. In Amerikansky ezhegodnik. 1971 (pp. 329-341). Moscow, Nauka.

Bolkhovitinov, N. N. (1997). O vremeni i o sebe: zametki istorika [About Time and Myself: Notes of a Historian]. In Istoriki Rossii, Iss. 1, pp. 70-79. Moscow, Nauka.

Bolkhovitinov, N. N. (2005). Vospominaniya [Memoirs]. 62 p. Moscow. [Otpechatannaya na mashinke rukopis' 62 stranits, kotoraya nachinaetsya frazoy "Schastlivaya pora detstva"]. (Original nakhoditsya u vdovy Bolkhovitinova, Lyudmily Antonovny Bolkhovitinovoy. Avtor ispol'zoval svoyu kopiyu originala).

Burin, S. N. (1991). K 75-letiyu akademika G. N. Sevost'yanova [To 75-years Celebration of Academician G. N. Sevostyanov]. In Amerikansky ezhegodnik. 1990 (pp. 211-215). Moscow, Nauka.

Butterfield, L. H. \& Levin E. (Transl.). (1975). Introduction. In Bolkhovitinov, N. N. The Beginnings of Russian-American Relations, 1775-1815 (pp. X-XVIII). Cambridge, Mass., Harvard University Press.

Cherkasov, P. (2004). IMEMO. Institut Mirovoy Ekonomiki i Mezhdunarodnykh Otnosheniy. Portret na fone epokhi [IMEMO. Institute of World Economy and International Relations. A Portrait at the Background of the Epoch]. 572 p. Moscow, Ves' mir.

Dash, B. L. (1982). A Defector Reports: The Institute of the USA and Canada. Falls Church, VA, Delphic Associates.

Dement'ev, I. P. (2004). Il'ya Savvich Galkin [Ilya Savvich Galkin]. In Sevost'yanov, G. N. (Ed.). Portrety istorikov : Vremya $i$ sud'by. Vol. 4. Novaya $i$ noveyshaya istoriya (pp. 105-123). Moscow, Nauka.

English, R. (2000). Russia and Idea of the West: Gorbachev, Intellectuals, and the End of the Cold War. 401 p. New York, Columbia University Press.

Galkin, I. S. (1998). Tropami moey zhizni: Na postu rektora MGU [Along the Paths of My Life: Being Rector of Moscow State University]. In Novaya i noveyshaya istoriya, 4, pp. 90-112; 5, pp. 111-132. 
Grigory Nikolaevich Sevost'yanov: [nekrolog]. [Grigory Nikolaevich Sevostyanov: Obituary]. (2013). In Novaya i noveyshaya istoriya, 3, pp. 245-248.

Gurevich, A. (2004). Istoriya istorika [History of a Historian]. 284 p. Moscow, ROSSPEN.

Gutnova, E. V. (2001). Perezhitoe [The Life Lived]. 462 p. Moscow, ROSSPEN.

Kartseva, E. (1965). Chto cheloveku nado [What a Human Needs]. In Sovetsky ekran, 2, p. 16.

Komissarov, B. N. (2002). As otechestvennoy amerikanistiki (k 70-letiyu N. N. Bolkhovitinova) [An Ace at the Russian American Studies (For N. N. Bolkhovitinov's $70^{\text {th }}$ Birthday Anniversary]. In Chubar'yan, A. O. (Ed.). Russkoe otkrytie Ameriki. Sbornik statey, posvyashchennyy 70-letiyu akademika Nikolaya Nikolaevicha Bolkhovitinova (pp. 5-36). Moscow, ROSSPEN.

Kurilla, I. \& Zhuravleva, V. I. (Eds.). (2015). Russian/Soviet Studies in the United States, Amerikanistika in Russia: Mutual Representations in Academic Projects. 306 p. Lanham, MD and Boulder, CO, Rowman and Littlefield's Lexington Press.

Markwick, R. D. (Raleigh, D. J. (Foreword)). (2001). Rewriting History in Soviet Russia: The Politics of Revisionist Historiography, 1956-1974. 327 p. New York, Palgrave. Medvedev, R. (1991). Lichnost' $i$ epokha: Politichesky portret L. I. Brezhneva

[Personality and Epoch: L.I. Brezhnev's Political Portrait]. 336 p. Moscow, Novosti.

Nekrich, A. (Lineburgh, D. (Transl.)). (1991). Forsake Fear: Memoirs of an Historian. 293 p. Boston, Unwin Hyman.

Novye chleny Akademii nauk SSSR [New Members of the Academy of Sciences of the

USSR]. (1988). In Vestnik Akademii nauk SSSR, Iss. 2, pp. 123-126. Moscow.

Pozner, V. V. (2013). Proshchanie s illyuziyami [A Farewell to Illusions]. 478 p. Moscow, AST.

Raleigh, D. J. (2012). Soviet Baby Boomers: An Oral History of Russia's Cold War Generation. 420 p. New York, Oxford University Press.

Roth-Ey, K. (2011). Moscow Prime Time: How the Soviet Union Built the Media Empire That Lost the Cultural Cold War. 315 p. Ithaca, Cornell University Press.

Zhuk, S. (2011). Closing and Opening Soviet Society (Introduction to the Forum Closed City, Closed Economy, Closed Society: The Utopian Normalization of Autarky). In Ab Imperio, 2, pp. 123-158.

Zhuk, S. I. (2013). 'Academic Détente': IREX Files, Academic Reports, and 'American' Adventures of Soviet Americanists during the Brezhnev Era. In Cahiers du monde russe, Janvier-juin, vol. 54, No. 1-2, pp. 297-328.

Zhuk, S. I. (2013). Inventing America on the Borders of Socialist Imagination: Movies and Music from the USA and the Origins of American Studies in the USSR. In Region: Regional Studies of Russia, Eastern Europe, and Central Asia, Vol. 2, No. 2, pp. 249-288.

The article was submitted on 05.03.2016 